\title{
Suitability of Kabanyolo Soils for Fruit and Vegetable Production
}

\author{
Paul Okiror ${ }^{1 *}$, Julius Bunny Lejju1, Joseph Bahati², Grace Kagoro Rugunda', \\ Collins Inno Sebuuwufu ${ }^{1}$, Patrick Mulindwa ${ }^{1}$, Jolly Joe Ocan ${ }^{3}$ \\ ${ }^{1}$ Faculty of Science, Mbarara University of Science and Technology, Mbarara, Uganda \\ ${ }^{2}$ School of Forestry, Environmental and Geographical Sciences, Makerere University, Kampala, Uganda \\ ${ }^{3}$ School of Engineering, Makerere University, Kampala, Uganda \\ Email: *pokiror@must.ac.ug
}

How to cite this paper: Okiror, P., Lejju, J.B., Bahati, J., Rugunda, G.K., Sebuuwufu, C.I., Mulindwa, P. and Ocan, J.J. (2017) Suitability of Kabanyolo Soils for Fruit and Vegetable Production. Open Journal of Soil Science, 7, 19-33.

https://doi.org/10.4236/ojss.2017.72002

Received: December 27, 2016

Accepted: February 4, 2017

Published: February 7, 2017

Copyright $\odot 2017$ by authors and Scientific Research Publishing Inc. This work is licensed under the Creative Commons Attribution International License (CC BY 4.0).

http://creativecommons.org/licenses/by/4.0/

\begin{abstract}
This paper presents results of soil analysis for samples extracted from Makerere University Agricultural Research Institute Kabanyolo. The study was aimed at ascertaining the suitability of MUARIK soils for fruit (pineapple, passion fruit and watermelon) and vegetable (cabbage, eggplant, tomato and pumpkin) growth, yield and maturity. Soil morphological, physical and chemical properties were probed by excavating a 1.86 meter soil profile pit and sampling soils in 9 equidistant locations at MUARIK. The soil morphology and physical properties were described using the Munsel colour chart and USDA classification system while chemical parameters were determined in Makerere University Soil Laboratory following procedures described by Okalebo et al. [1]. Three pedon layers (RSK-H1, RSK-H3 and RSK-H5) had gradual boundaries while RSK-H4 was continuous. However, RSK-H2 and RSK-H6 had abrupt boundary layers. The texture of the profiles was clayey (52\%). The soils were acidic with a pH of 6.08 (sub soil) to 6.12 (top soil). On comparison with standard requirements for target fruits and vegetables, the site was deficient in most of the minerals including $\mathrm{P}(8.88-12.42 \mathrm{pmm}), \mathrm{Ca}(6.46-7.92 \mathrm{pmm}), \mathrm{K}$ (0.06 - $0.47 \mathrm{pmm}), \mathrm{Mg}(1.37-1.70 \mathrm{pmm}), \mathrm{Na}(0.17-0.23 \mathrm{pmm}), \mathrm{N}(0.18-0.19$ $\mathrm{pmm})$, and soil organic matter $(4.53 \%-4.81 \%)$. Sand and clay had the highest negative significant correlation $(r=-0.94, \mathrm{p}<0.01)$ in the top soil. The highest positive significant correlation was observed between $\mathrm{Ca}$ and $\mathrm{Mg}$ both in the topsoil $(\mathrm{r}=0.96, \mathrm{p}<0.01)$ and subsoil $(\mathrm{r}=0.99, \mathrm{p}<0.01)$. MUARIK is suitable for growing cabbage and pumpkin. However, for improved growth, yields and maturity, the soils should be amended with manure (watermelon), lime (passion fruit and tomato) and sulphur (eggplant and pineapples).
\end{abstract}

\section{Keywords}

Fruits, Kabanyolo, Vegetables, Soil, Suitability 


\section{Introduction}

Uganda's soils are classified into six (6) major types notably: Soils of high productivity ( $8 \%$ of the land area), Soils of medium productivity (14\%), Soils of fair productivity (43\%), Soils of low productivity $(30 \%)$ while the Soils of negligible productivity constitute $5 \%$ of the land area. In addition, the country's main soil types are 18 divided into 7 groups based on their occurrence and agricultural productivity. These include: 1) the Uganda surfaces cover most areas south of Lake Kyoga. This group embraces five types of deep, sandy clay loams with medium to high productivity. 2) Tanganyika surfaces cover most areas north of Lake Kyoga, West Nile and some parts of the South Western tip of Uganda, embracing five types of sandy clay loam with low to medium productivity. 3) Karamoja surfaces cover the North Eastern part of the country and include two soil types of sandy clay loams and black clays with very low productivity. 4) Rift valley soils in the Western and Northern parts of the country, bordering on the Western Rift Valley, embracing two types of mainly sandy clay loams with alluvial parent rock of medium to high productivity. 5) Volcanic soils are dominant in Mt. Elgon, Northern Karamoja, and the extreme South Western tip of Uganda (Kabale and Kisoro) with medium to high productivity except in N. Karamoja where their productivity is reportedly low. 6) Alluvial soils are found outside the Rift Valley, mainly in Central Northern Uganda (Lango and Acholi) as well as West of Lake Victoria. The productivity of these sandy soils is very low. 7) The last group of soil types is in Northern Uganda and their productivity is low [2].

Despite this broad soil classification, fruits and vegetables have specific soil requirements for growth, high yields and maturity. Eggplants, for example, can be grown with considerable success in fine and rich loam soils that are deep and well-drained. The soil $\mathrm{pH}$ should range from 5.5 to 6.0 for its better growth and development. As the crop remains in the field for a number of months therefore, the soils should be well prepared by being ploughed 4 - 5 times before transplanting the seedlings. When the field is well prepared and leveled, the beds of suitable size should be made in the field before transplanting. However, in most fields, mineral supplies to crops $\left(\mathrm{N}+\mathrm{P}_{2} \mathrm{O}_{5}+\mathrm{K}_{2} \mathrm{O}\right)$ are always lower than the recommended quantities and imbalanced with excess of Nitrogen due to inappropriate use of urea [3]. The mineral bill is $100(\mathrm{~kg}$ of N$)$ - $100\left(\mathrm{~kg}\right.$ of $\left.\mathrm{P}_{2} \mathrm{O}_{5}\right)-200\left(\mathrm{~kg}\right.$ of $\left.\mathrm{K}_{2} \mathrm{O}\right)$ for African eggplant. According to Nono-Womdim et al. [3], eggplants require 1 - 3 applications of the growth fertilizer a week until early fruit formation whereby a development fertilizer will be applied.

Tomato grows well in sandy loam soil with well-drained clay subsoil. Light soils are good for early variety [3]. While clay loam or silt loam soils are well suited for heavy yield, tomato grows at $\mathrm{pH} 6.0$ to 7.0 satisfactorily. The soil should be well prepared and leveled by ploughing the land 4 - 5 times. Similarly, pumpkins may be grown on a wide range of soil types provided the soil is free- 
draining. They are tolerant of fairly acid conditions and liming should not be necessary unless the $\mathrm{pH}$ is less than 5.5 [3]. Well-drained soils that warm rapidly are ideal for the production of the quick-maturing pumpkins. Friable loams with an abundance of organic matter and the capacity to retain moisture are ideal. A deep, friable seedbed should be prepared for improved pumpkin growth and yield.

As for leafy vegetables such as cabbages, a balanced ratio between nitrogen and potassium supplies is needed for maximum yield. Cabbages grow on a wide range of soil types ranging from light sand to heavier clays. Cabbages are divided into three main groups: ballhead (or roundhead), conical and the large drumhead types. Soils with high organic matter give the best yields. Soil $\mathrm{pH}$ should be in the range of 6.0 - 6.5 for cabbage growth and clubroot control [3].

Although, soil tests are useful in determining the availability of nutrients and fertiliser requirements prior to fruit and vegetable cultivation [4], the soil morphological and physico-chemical features of the Makerere University Agricultural Research Institute (MUARIK) remain largely unclear. Relatedly, much as Pomeroy [5] undertook a detailed survey of termite mounds in the central parts of Uganda, Wakiso district and MUARIK in particular, was left out. A study by Tenywa et al. [6], focused on the resilience and degradation stress of soils at MUARIK. Additionally, Okwakol and Sekamatte [7] studied the soil macrofauna in Uganda but recommended regular assessment of soil features in agricultural landscapes.

It was therefore important to undertake soil tests at MUARIK as a precursor for propagation of priority fruits (pineapple, passion fruit and watermelon) and vegetables (cabbage, eggplant, tomato and pumpkin). Fungo et al. [8] assert that precision agriculture requires site specific modeling of soil properties. Soil analysis was conducted because soil conditions usually influence the growth of fruits and vegetables [8] [9] [10]. In addition, incidence of pests and diseases depend on soil and weather conditions of a site.

\section{Materials and Methods}

\subsection{Description of Study Area}

The study was conducted at Makerere University Agricultural Research Institute Kabanyolo (Figure 1). MUARIK is located on spatial coordinates $0^{\circ} 27^{\prime} 60^{\prime \prime} \mathrm{N}$, $32^{\circ} 36^{\prime} 24^{\prime \prime} \mathrm{E}$ at an altitudinal range of $1250 \mathrm{~m}$ to $1320 \mathrm{~m}$ above mean sea level [11]. The study site is within the administrative boundaries of Nangabo Sub County, Wakiso district and about $14 \mathrm{~km}$ north of Kampala, Uganda's capital city. Kabanyolo is part of the Lake Victoria basin that receives an average annual precipitation of $1218 \mathrm{~mm}$ and slightly drier periods in June to July and December to February. The average annual temperature is $21.5^{\circ} \mathrm{C}$ [12].

Agricultural research and demonstrations are the main activities conducted at MUARIK by the Makerere University College of Agricultural and Environmental Sciences and collaborating institutions. The institute conducts several agri- 


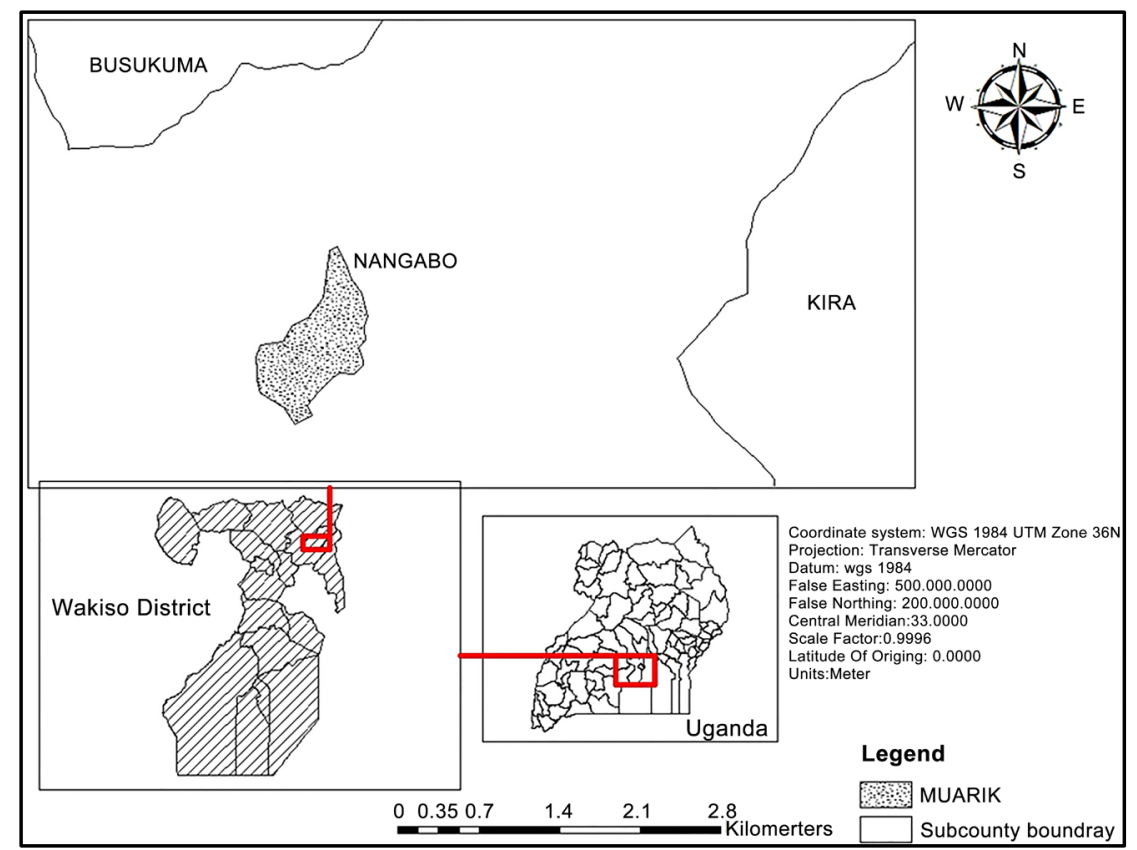

Figure 1. Map of Uganda showing the location of MUARIK.

culture and rural innovation research projects. However, as part of the Buganda surface, the predominant farming system around MUARIK is the banana-coffee system [13]. According to the map (Figure 1), MUARIK occupies 3 square miles of land. Yost and Eswaran [11] indicated the MUARIK soils to be formed on residuum and colluvium from quartzites, gneiss and basement complex rocks. On the side slopes, colluvium enriched with lateritic gravel is common. This study was aimed at ascertaining the current morphological, physical and chemical properties of soil that may influence fruit and vegetable growth, yield and maturity.

\subsection{Soil Sampling}

The influence of soil depth of on soil properties at the experimental site was probed by excavating, describing and sampling soil in a 1.86 meter deep soil profile pit following Okia [14]. The pit was located at the centre of the experimental site. Surrounding the soil profile pit were sweet potato, passion fruit plants and a 1 year fallow. The soil profile was described in terms of depth, number of horizons, width of each horizon and boundary distinctness between horizons following Okia [14], Fungo et al. [8] and Szymański et al. [15]. A linear tape (Colt Germany $5 \mathrm{~m}$ ) was used to measure the profile depth while distinctness of the horizon boundaries was described as abrupt (a), gradual (g), clear (c) and diffuse (d). The Munsell colour chart was used to provide standard descriptions and the colour name for each horizon. Okia [14] asserts that the Munsell colour system specifies colour based on three colour dimensions: hue (predominant spectral colour), value (lightness and darkness against a neutral gray scale) and chroma (purity or richness). This method of soil colour analysis is described in MCC [16]. Other scholars [15] [17] support the use of the Munsell colour soil 
charts to describe color of the soil material in moist state. In each horizon, about $500 \mathrm{~g}$ of soil was collected by chiselling, placed in plastic sample bags, labelled, packed in a sample box (Marina cooler 24S) and delivered to Makerere University Soil Laboratory for further processing and analysis. A similar approach was used by Okia [14] and Fungo et al. [8].

In addition, to ascertain soil properties across the site and thus site suitability for the propagation of fruits and vegetables, three (3) patches within MUARIK were selected. The patches were selected in locations that represented different land uses and the elevations. Site conditions included a sweet potato field and the 1 year fallow. Three (3) sampling points that were equidistant from each other, separated by 50 and $30 \mathrm{~m}$ across and along the slope, were placed along the contour of each patch. Soil samples were taken at two (2) depths including 0 to 20 and $20-40 \mathrm{~cm}$ as done by Fungo et al. [8]. A total of 18 samples were therefore obtained from across the experimental site.

\subsection{Laboratory Analysis of Soils}

Soil samples were double labelled and transported to Makerere University Soil Science laboratory for drying, preparation and subsequent analyses. Parameters determined included soil organic matter (OM), $\mathrm{pH}, \mathrm{N}, \mathrm{P}, \mathrm{K}, \mathrm{Ca}, \mathrm{Mg}$ and $\mathrm{Na}$. Available Phosphorus (P) was determined by using Bray and Kurtz No. 1 method [18]. The soil was extracted by Brady 1 solution and the $\mathrm{P}$ determined by the calorimetric procedure using a spectrophotometer. Soil $\mathrm{pH}$ was ascertained using a $\mathrm{pH}$ meter as done by Rhoades [19]. Exchangeable $\mathrm{K}$, Ca and $\mathrm{Mg}$ were measured by treating the soil samples with excess $1 \mathrm{M}$ ammonium acetate solution. Later, the concentrations of exchangeable $\mathrm{Na}$ and $\mathrm{K}$ in the extract were measured by flame photometer and the concentration of $\mathrm{Ca}$ and $\mathrm{Mg}$ was measured by atomic absorption spectrophotometry [20].

Considering the limitation of the field method for determination of soil texture, particle size analysis was performed in the laboratory using the pipette method. Since soil texture refers to the relative proportions of sand, silt, and clay particles in a mass of soil, this method applies Stokes' Law to measure settling rates of different soil particles in a given soil sample [1]. The proportions of sand, clay and silt in each soil sample were then applied to the soil textural class estimation chart (texture triangle) to derive the respective textural classes [17]. The textual classes were recorded as sand (s), loam (l), loamy sand (ls), clay loam (cl), sandy loam (sl), clay (c), sandy clay loam (scl), silt (si), sandy clay (sc), silt loam (sil) silty clay loam (sicl), and silty clay (sic) based on the United States Department of Agriculture (USDA) soil textural classes [21] following Okia [14].

\subsection{Data Analysis}

Laboratory data on soil texture and minerals was entered in MS Excel to generate frequencies, means, standard errors of the means, coefficients of variation, percentages and correlation coefficients. Correlations were run to ascertain the 
strengths and directions of associations between soil physical and chemical parameters. The results were presented in tables and charts as done by Okia [14], Fungo et al. [8] and Szymański et al. [15].

\section{Results}

\subsection{Soil Morphology}

The field description of the morphology of the studied soil profiles is given in Table 1. Three pedon layers (RSK-H1, RSK-H3 and RSK-H5) had gradual boundaries while RSK-H4 was continuous. However, the second pedon (RSK-H2) and the last (RSK-H6) had abrupt boundary layers. The first three horizons were soft to slightly hard with some roots. The last three horizons ranged from hard to very hard to hard consistence with few to no roots. The upper part of the studied pedons (RSK-H1 and RSK-H2) shows a dark yellowish brown (10YR 4/4) or dark brown (7.5YR 4/4) colour. The rest of the pedons were yellowish red with the colour codes of 5YR5/6 for RSK-H3 and RSK-H4 and 5YR5/6 in RSKH5 and RSK-H6 (Table 1).

\subsection{Physical Properties}

The texture of the studied soil profiles, in the $1.86 \mathrm{~m}$ pit, was generally clay (Table 2). The clay fraction clearly dominated and ranged from $40 \%$ to $62 \%$ with an average of 52\%. The upper part of the pedons (i.e. RSK-H1 and RSK-H2 horizons) contained a smaller clay fraction (i.e. 40\% - 44\%) in comparison with the lower part. The highest amount of clay $(62 \%)$ was recorded in the $4^{\text {th }}$ Horizon (RSK-H4). Amount of the sand fraction ranges from $35 \%$ to $52 \%$ and was almost evenly distributed throughout the studied profiles (except the RSK-H3) with an average of $43 \%$. Silt fraction was the least ranging from $1 \%$ to $8 \%$, with a mean of $5 \%$. Based on the USDA textual classification, the top and the $5^{\text {th }}$ pedons were sandy clay (sc) while the rest (RSK-H3, RSK-H4 and RSK-H6) were clay (c). When data was pooled, the overall textual classification is clay (Figure 2). Clay had an average of $52 \%$, followed by sand at $43 \%$ and distant silt with $5 \%$.

Table 1. Field description of the studied soils.

\begin{tabular}{ccccccc}
\hline $\begin{array}{c}\text { Site } \\
\text { Horizon }\end{array}$ & $\begin{array}{c}\text { Depth } \\
(\mathrm{cm})\end{array}$ & $\begin{array}{c}\text { Boundary } \\
\text { Distinctness }\end{array}$ & Roots & Consistency & Colour (moist) & Colour name \\
\hline RSK-H1 & $0-26$ & $\mathrm{~g}$ & +++ & Soft & 10 YR4/4 & $\begin{array}{c}\text { Dark yellowish } \\
\text { brown }\end{array}$ \\
RSK-H2 & $26-42$ & $\mathrm{a}$ & ++ & Soft & 7.5 YR4/4 & Dark brown \\
RSK-H3 & $42-80$ & $\mathrm{~g}$ & + & Slightly hard & 5 5R5/6 & Yellowish red \\
RSK-H4 & $80-112$ & $\mathrm{c}$ & Few & Hard & $5 Y R 5 / 6$ & Yellowish red \\
RSK-H5 & $112-165$ & $\mathrm{~g}$ & Absence & Very hard & $5 Y R 5 / 8$ & Yellowish red \\
RSK-H6 & $165-190$ & a & Absence & Hard & $5 Y R 5 / 8$ & Yellowish red \\
\hline
\end{tabular}

${ }^{\star} \mathrm{RSK}=\mathrm{RELOAD}$ Site Kabanyolo ${ }^{* *} \mathrm{H} 1$ to $\mathrm{H} 6=$ Soil horizons in the profile pit; ${ }^{\star * *}$ Abrupt (a), gradual (g), clear (c) diffuse (d); $+++=$ Horizon has $50 \%$ root coverage; $++=$ Horizon has $25 \%$ root coverage; $+=$ Horizon has $15 \%$ root coverage [8] [14] [15] [16]. 


\subsection{Chemical Properties}

Across the study site, the soils were generally acidic with a $\mathrm{pH}$ of $6.12 \pm 0.15$ in the top soil and $6.08 \pm 0.11$ in the subsoil layer (Table 3 ). The mean value of phosphorus was $12.42 \pm 3.65$ in the top soil compared to $8.88 \pm 3.2$ in the sub soil. Whereas $\mathrm{Ca}, \mathrm{K}, \mathrm{Mg}, \mathrm{Na}, \mathrm{N}, \mathrm{OM}$, Sand and Silt were $7.92 \pm 0.76,0.47 \pm 0.13$, $1.70 \pm 0.17,0.23 \pm 0.05,0.19 \pm 0.01,4.81 \pm 0.35,54.44 \pm 2.64$ and $7.22 \pm 0.87$ on average in the top soil, these parameters were $6.46 \pm 0.74,0.29 \pm 0.06,1.37 \pm$ $0.16,0.17 \pm 0.02,0.18 \pm 0.02,4.53 \pm 0.15,52.56 \pm 1.68$ and $6.67 \pm 1.22$ in the subsoil horizon respectively (Table 3 ). Phosphorus was the most variable in both the top and sub soil, considering the absolute value of the coefficient of variation of 88.2 and 108.1 respectively. Whereas $\mathrm{pH}$ was the least variable property in both the top soil $(\mathrm{CoV}=7.2)$ and subsoil layer $(\mathrm{CoV}=5.3)$. Besides clay, all the soil properties we investigated were higher in the top soil than the subsoil horizon. The average clay composition was $38.33 \pm 2.66$ in the top soil compared to $40.78 \pm 2.7$ in the sub layer (Table 3 ).

Table 2. Some physical properties of the investigated soil profiles.

\begin{tabular}{cccccc}
\hline Site-Horizon & Depth $(\mathrm{cm})$ & \% of sand & \% of clay & \% of silt & $\begin{array}{c}\text { USDA textual } \\
\text { class }^{* * *}\end{array}$ \\
\hline RSK-H1 & $0-26$ & 52 & 40 & 8 & $\mathrm{sc}$ \\
RSK-H2 & $26-42$ & 50 & 44 & 6 & $\mathrm{sc}$ \\
RSK-H3 & $42-80$ & 35 & 62 & 3 & $\mathrm{c}$ \\
RSK-H4 & $80-112$ & 38 & 56 & 6 & $\mathrm{c}$ \\
RSK-H5 & $112-165$ & 45 & 54 & 1 & $\mathrm{sc}$ \\
RSK-H6 & $165-190$ & 38 & 56 & 6 & $\mathrm{c}$ \\
\hline
\end{tabular}

${ }^{* * *}$ sandy clay (sc), clay (c).

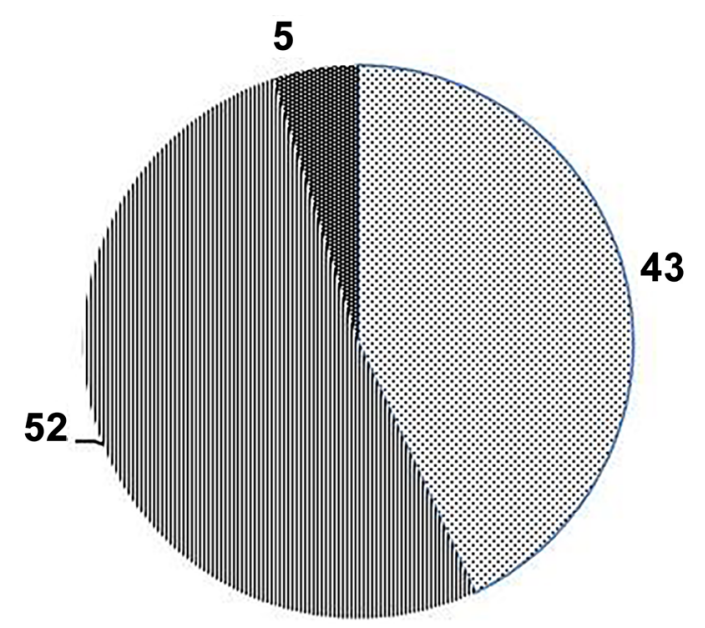

Sand $\quad$ IIIII Clay Silt

Figure 2. Soil texture. 
Table 3. Descriptive statistics of the top and sub soils.

\begin{tabular}{|c|c|c|c|c|c|c|c|c|c|c|c|}
\hline Statistic & $\mathrm{pH}$ & $\begin{array}{c}\mathbf{P} \\
(\mathrm{ppm})\end{array}$ & $\begin{array}{c}\mathrm{Ca} \\
(\mathrm{ppm})\end{array}$ & $\begin{array}{c}\mathrm{K} \\
(\mathrm{ppm})\end{array}$ & $\begin{array}{c}\mathrm{Mg} \\
(\mathrm{ppm})\end{array}$ & $\begin{array}{c}\mathrm{Na} \\
(\mathrm{ppm})\end{array}$ & $\begin{array}{l}\mathrm{N} \\
(\%)\end{array}$ & $\begin{array}{l}\text { OM } \\
(\%)\end{array}$ & $\begin{array}{c}\text { Sand } \\
(\%)\end{array}$ & $\begin{array}{l}\text { Silt } \\
\text { (\%) }\end{array}$ & $\begin{array}{l}\text { Clay } \\
(\%)\end{array}$ \\
\hline \multicolumn{12}{|c|}{ Top Soil } \\
\hline Mean & 6.12 & 12.42 & 7.92 & 0.47 & 1.70 & 0.23 & 0.19 & 4.81 & 54.44 & 7.22 & 38.33 \\
\hline $\begin{array}{l}\text { Standard Error } \\
\text { of the Mean }\end{array}$ & 0.15 & 3.65 & 0.76 & 0.13 & 0.17 & 0.05 & 0.01 & 0.35 & 2.64 & 0.87 & 2.66 \\
\hline $\begin{array}{l}\text { Coefficient of } \\
\text { Variation }\end{array}$ & 7.20 & 88.20 & 28.85 & 85.36 & 30.23 & 66.20 & 12.79 & 21.84 & 14.53 & 36.04 & 20.86 \\
\hline \multicolumn{12}{|c|}{ Sub Soil } \\
\hline Mean & 6.08 & 8.88 & 6.46 & 0.29 & 1.37 & 0.17 & 0.18 & 4.53 & 52.56 & 6.67 & 40.78 \\
\hline $\begin{array}{l}\text { Standard Error } \\
\text { of the Mean }\end{array}$ & 0.11 & 3.20 & 0.74 & 0.06 & 0.16 & 0.02 & 0.02 & 0.15 & 1.68 & 1.22 & 2.13 \\
\hline $\begin{array}{l}\text { Coefficient of } \\
\text { Variation }\end{array}$ & 5.28 & 108.07 & 34.14 & 59.72 & 33.98 & 41.72 & 30.87 & 10.06 & 9.58 & 54.77 & 15.67 \\
\hline
\end{tabular}

A correlation matrix (Table 4) showed that sand and clay had the highest negative significant correlation $(\mathrm{r}=-0.94, \mathrm{p}<0.01)$ while $\mathrm{Ca}$ and $\mathrm{Mg}$ had the highest positive significant correlation $(r=0.96, \mathrm{p}<0.01)$ in the top soil. Soil $\mathrm{pH}$ was highly correlated negatively with sand in the subsoil $(\mathrm{r}=-0.88, \mathrm{p}<0.01)$ whereas $\mathrm{Ca}$ and $\mathrm{Mg}$ had the highest positive significant correlation ( $\mathrm{r}=0.99, \mathrm{p}<$ $0.01)$ in the sub-soil layer. Phosphorus and silt did not show any relationship with soil $\mathrm{pH}$ in both the top ( $\mathrm{p}>0.05)$ and sub-soil layers $(\mathrm{p}>0.05)$. In the topsoil, only silt did not show a significant relationship with soil $\mathrm{P}$ and $\mathrm{Ca}$. In addition, $\mathrm{Na}$ was not significantly $(\mathrm{p}>0.05)$ correlated with $\mathrm{K}$ and $\mathrm{N}$ in the top soil layer.

Having carefully reviewed the contents of Table 4, this paragraph should read as follows: in the subsoil, $\mathrm{pH}$ had no significant $(\mathrm{p}>0.05)$ relationship with $\mathrm{P}$ or silt. In addition, $\mathrm{P}$ was not significantly $(\mathrm{p}>0.05)$ influenced by $\mathrm{Ca}, \mathrm{OM}$ or Silt. Other insignificant ( $\mathrm{p}>0.05$ ) relationships in the sub soil were between $\mathrm{Ca}$ and Silt, $\mathrm{K}$ and $\mathrm{Na}, \mathrm{K}$ and $\mathrm{N}, \mathrm{Na}$ and $\mathrm{N}$, and $\mathrm{OM}$ and Silt (Table 4).

\subsection{Comparison of MUARIK Soil with Requirements for Fruit and Vegetable Production}

The comparison of key MUARIK soil parameters with the standard requirements for fruits and vegetable propagation is presented in Table 5. Soil organic matter and minerals including $\mathrm{Ca}, \mathrm{K}, \mathrm{Mg}, \mathrm{Na}$ and $\mathrm{N}$ were generally lower than the requirement for fruits and vegetable propagation. The soil $\mathrm{pH}$ is slightly favorable for water melon, cabbage and pumpkins but unsuitable for pineapple, passion fruits, egg plant and tomato. The predominantly clayey (av. 52\%) soil texture could tolerate pumpkins and cabbages but may not be suitable for the rest of the target fruits and vegetables (Table 5). 
Table 4. Spearman's Correlations of field based soil properties of top and sub soils.

\begin{tabular}{|c|c|c|c|c|c|c|c|c|c|c|}
\hline Parameter & $\mathrm{pH}$ & $\begin{array}{c}\mathbf{P} \\
(\mathrm{ppm})\end{array}$ & $\begin{array}{c}\mathrm{Ca} \\
(\mathrm{ppm})\end{array}$ & $\begin{array}{c}\mathrm{K} \\
(\mathrm{ppm})\end{array}$ & $\begin{array}{c}\mathrm{Mg} \\
(\mathrm{ppm})\end{array}$ & $\begin{array}{c}\mathrm{Na} \\
(\mathrm{ppm})\end{array}$ & $\begin{array}{c}\mathrm{N} \\
(\%)\end{array}$ & $\begin{array}{l}\text { OM } \\
(\%)\end{array}$ & $\begin{array}{c}\text { Sand } \\
(\%)\end{array}$ & $\begin{array}{l}\text { Silt } \\
(\%)\end{array}$ \\
\hline \multicolumn{11}{|l|}{ Top Soil } \\
\hline \multicolumn{11}{|l|}{$\mathrm{pH}$} \\
\hline $\mathrm{P}(\mathrm{ppm})$ & -0.03 & & & & & & & & & \\
\hline $\mathrm{Ca}(\mathrm{ppm})$ & $0.79^{*}$ & 0.05 & & & & & & & & \\
\hline $\mathrm{K}(\mathrm{ppm})$ & $0.68^{* *}$ & $-0.20^{* *}$ & $0.68^{* *}$ & & & & & & & \\
\hline $\mathrm{Mg}(\mathrm{ppm})$ & $0.72^{\star \star}$ & $0.05^{\star *}$ & $0.96^{\star \star}$ & $0.69^{* *}$ & & & & & & \\
\hline $\mathrm{Na}(\mathrm{ppm})$ & $0.57^{\star *}$ & $-0.33^{* *}$ & $0.51^{\star *}$ & 0.93 & $0.45^{\star *}$ & & & & & \\
\hline N (\%) & $0.36^{\star *}$ & $0.56^{\star *}$ & $0.33^{* *}$ & $0.40^{*}$ & $0.46^{* *}$ & 0.17 & & & & \\
\hline $\mathrm{OM}(\%)$ & $0.36^{\star *}$ & $-0.19^{*}$ & $0.32^{\star *}$ & $0.30^{* *}$ & $0.26^{* *}$ & $0.27^{\star *}$ & $-0.39^{* *}$ & & & \\
\hline Sand (\%) & $0.32^{* *}$ & $-0.04^{* *}$ & $0.47^{\star *}$ & $0.73^{* *}$ & $0.55^{\star *}$ & $0.60^{* *}$ & $0.16^{* *}$ & $0.52^{\star *}$ & & \\
\hline Silt (\%) & 0.07 & 0.44 & 0.30 & $0.10^{* *}$ & $0.38^{* *}$ & $-0.02^{\star *}$ & $0.67^{\star *}$ & $-0.69^{*}$ & $-0.13^{\star \star}$ & \\
\hline Clay (\%) & $-0.34^{* *}$ & $-0.10^{* *}$ & $-0.56^{\star *}$ & $-0.75^{\star *}$ & $-0.66^{* *}$ & $-0.59^{* *}$ & $-0.38^{\star *}$ & $-0.29^{* *}$ & $-0.94^{* *}$ & $-0.21^{\star *}$ \\
\hline \multicolumn{11}{|l|}{ Sub Soil } \\
\hline \multicolumn{11}{|l|}{$\mathrm{pH}$} \\
\hline $\mathrm{P}(\mathrm{ppm})$ & -0.19 & & & & & & & & & \\
\hline $\mathrm{Ca}(\mathrm{ppm})$ & $0.20^{\star *}$ & 0.83 & & & & & & & & \\
\hline $\mathrm{K}(\mathrm{ppm})$ & $0.25^{\star *}$ & $0.49^{*}$ & $0.81^{* *}$ & & & & & & & \\
\hline $\mathrm{Mg}(\mathrm{ppm})$ & $0.31^{\star *}$ & $0.78^{*}$ & $0.99^{* *}$ & $0.81^{* *}$ & & & & & & \\
\hline $\mathrm{Na}(\mathrm{ppm})$ & $0.58^{\star *}$ & $-0.19^{*}$ & $0.16^{* *}$ & 0.08 & $0.19^{\star *}$ & & & & & \\
\hline N (\%) & $0.38^{\star *}$ & $-0.12^{*}$ & $-0.19^{\star *}$ & -0.31 & $-0.14^{* *}$ & -0.19 & & & & \\
\hline OM (\%) & $0.09^{* *}$ & 0.11 & $0.29^{*}$ & $0.32^{* *}$ & $0.34^{\star *}$ & $-0.39^{* *}$ & $0.21^{* *}$ & & & \\
\hline Sand (\%) & $-0.88^{\star *}$ & $0.06^{* *}$ & $-0.42^{\star *}$ & $-0.58^{\star *}$ & $-0.48^{* *}$ & $-0.49^{* *}$ & $-0.29^{* *}$ & $-0.23^{* *}$ & & \\
\hline Silt (\%) & -0.34 & 0.30 & 0.29 & $0.56^{* *}$ & $0.26^{* *}$ & $-0.27^{* *}$ & $-0.30^{* *}$ & -0.04 & $0.06^{* *}$ & \\
\hline Clay (\%) & $0.88^{\star *}$ & $-0.22^{\star *}$ & $0.16^{* *}$ & $0.14^{* *}$ & $0.23^{* *}$ & $0.54^{\star \star}$ & $0.40^{\star \star}$ & $0.20^{\star *}$ & $-0.82^{\star \star}$ & $-0.62^{\star \star}$ \\
\hline
\end{tabular}

Values with ${ }^{*}$ and ${ }^{*}$ were significantly correlated at 0.05 and 0.01 alpha level, respectively.

Table 5. Comparison of MUARIK soil with requirements for fruits and vegetables.

\begin{tabular}{|c|c|c|c|c|c|c|c|c|}
\hline \multirow{3}{*}{ Parameter } & \multirow{3}{*}{ MUARIK soils } & \multicolumn{7}{|c|}{ Comparisons } \\
\hline & & \multicolumn{3}{|c|}{ Requirements for fruits } & \multicolumn{4}{|c|}{ Requirements for vegetables } \\
\hline & & Pineapples & Passion fruit & Watermelon & Cabbage & Tomato & Egg plant & Pumpkin \\
\hline $\mathrm{pH}$ & $6.08-6.12$ & $\star 5$ & 2 & 3 & 3 & 2 & 4 & 3 \\
\hline $\mathrm{P}(\mathrm{ppm})$ & $8.88-12.42$ & 2 & 2 & 2 & 2 & 2 & 2 & 2 \\
\hline $\mathrm{Ca}(\mathrm{ppm})$ & $6.46-7.92$ & 1 & 1 & 1 & 1 & 1 & 1 & 1 \\
\hline $\mathrm{K}(\mathrm{ppm})$ & $0.29-0.47$ & 1 & 1 & 1 & 1 & 1 & 1 & 1 \\
\hline $\mathrm{Mg}(\mathrm{ppm})$ & $1.37-1.70$ & 1 & 1 & 1 & 1 & 1 & 1 & 1 \\
\hline $\mathrm{Na}(\mathrm{ppm})$ & $0.17-0.23$ & 1 & 1 & 1 & 1 & 1 & 1 & 1 \\
\hline $\mathrm{N}(\mathrm{ppm})$ & $0.18-0.19$ & 1 & 1 & 1 & 1 & 1 & 1 & 1 \\
\hline Organic Matter (\%) & $4.53-4.81$ & 1 & 1 & 1 & 1 & 1 & 1 & 1 \\
\hline Clay (\%) & $38.33-62.00$ & 5 & 4 & 5 & 3 & 5 & 4 & 3 \\
\hline
\end{tabular}

${ }^{*} 1$ = Very low; 2 = Low; 3 = Moderate; $4=$ High; 5 = Very high for target fruits (Pineapple, Watermelon, Passion fruits) and vegetables such as Cabbage, Eggplant, Tomato and Pumpkin [22] [23] [24]. 


\section{Discussion}

\subsection{Soil Morphology}

A half of the horizons (RSK-H1, RSK-H3 and RSK-H5) had gradual boundaries while RSK-H5 was continuous. However, the second pedon (RSK-H2) and the last (RSK-H6) had abrupt boundary layers (Table 1). Similar results were obtained by Okia [14] along the Balanites aegyptiaca belt in Uganda. Accordingly, abrupt boundaries between horizons are indicative of highly weathered soils. These boundaries also indicate that the soils have experienced some anthropogenic disturbance [14].

The first three pedon layers were soft to slightly hard with some roots (Table 1). The last three horizons ranged from hard to very hard to hard consistence with few to no roots. These results concur with findings by Szymański et al. [15]. Such morphology indicates that the pedons could have resulted from the translocation of colloids (clay minerals and iron oxides) and cyclic reduction-oxidation processes [25] [26].

The upper part of the studied pedons (RSK-H1 and RSK-H2) had dark yellowish brown to dark brown colour. The rest of the pedons were yellowish red (Table 1). Earlier classification of MUARIK soil by Yost and Eswaran [11] indicated the surface layer to be dark reddish brown and the sub soil to be red neutral. The changes in soil colour over time could be attributed to the translocation of colloids and reduction-oxidation processed triggered by cultivation of research fields at MUARIK.

\subsection{Physical Properties}

The texture of the studied soil profiles was generally clay (Table 2 and Figure 2). According to Mugagga et al. [27], the percentage of clay, in particular, gives a clear indication of the problem nature of the soils. A $10 \%$ clay threshold has been used as an indicator of the expansion potential, whilst $32 \%$ clay content exhibits extreme expansion potential [28]. Such clay content has implications for the shrink-swell properties of the soil. Yang et al. [29] and Wati et al. [30] agree that fine-textured clayey soils have small pores and liberate water gradually, which renders them susceptible to water logging because of their high water retention capacity. Such soils may not be suitable for some fruit and vegetable propagation such as water melon that require well drained soils. Similarly, pumpkins may be grown on a wide range of soil types provided the soil is free-draining. However, cabbage grows on a wide range of soil types ranging from light sand to heavier clays. Cabbage could therefore be recommended at MUARIK.

A report by Morton [22] showed that passion fruit vines could be grown on many soil types but light to heavy sandy loams, of medium texture are most suitable. Good drainage is also essential to minimize the incidence of collar rot. This implies that passion fruits may not present high yields at MUARIK that is predominately clay. Furthermore, watermelon grows best on soils with a sandy 
loamy texture. It requires good drainage at site and therefore clayey, damp, and water-logged soil must be avoided [23]. This revelation points to inadequacy of the MUARIK soils that are mainly clayey to support watermelon production.

According to DAF [24], the best soils for pineapple production are non-compacted, well-aerated and free-draining loams, sandy loams and clay loams with no heavy clay or rock within one meter of the surface. Well drained soils are essential because poor drainage makes the plant more susceptible to root and heart rot diseases owing to a weak rooting system [24]. The fact that MUARIK has predominantly clayey soils makes the site unsuitable for pineapple growing except after remediation action is undertaken on the soil. In addition, eggplants can be grown with considerable success in fine and rich loam soils that are deep and well-drained [3]. Eggplant propagation at MUARIK should therefore be preceded by fertilizer application for better growth and development.

The upper part of the pedons (i.e. RSK-H1 and RSK-H2 horizons) contained a smaller clay fraction (i.e. 40\% - 44\%) in comparison with the lower part (Table 2 ). The highest amount of clay (62\%) was recorded in the $4^{\text {th }}$ Horizon (RSK-H4). Amount of the sand fraction ranges from $35 \%$ to $52 \%$ and is almost evenly distributed throughout the studied profiles (except the RSK-H3) with an average of $43 \%$. MUARIK could therefore be favourable for tomatoes which are reported by Muzaale [31] to grow well in sandy loam soil with well-drained clay subsoil.

\subsection{Chemical Properties}

The MUARIK soils are generally acidic with a $\mathrm{pH}$ of 6.12 in the top soil and 6.08 in the subsoil layer (Table 3 ). Soil $\mathrm{pH}$ is the measure of the acidity or alkalinity of the soil. The results in Table 3 concur with Majaliwa [32] who reported MUARIK soils to be acidic. Previous studies have provided possible scenarios for low soil $\mathrm{pH}$ in a site. Fungo et al. [8] noted that frequent cultivation may result in rapid decomposition of organic matter and weakening of soil structure, which later results in lowering soil pH. Relatedly, Steenwerth et al. [10] found lower values of soil $\mathrm{pH}$ in the grassland than in cultivated soils, reportedly due to leaching in the grasslands. Mulumba [9] reported some cropping systems to pose acidifying risk to the soil due to the amount of materials removed at harvest, amount and type of fertilizers normally used.

Muzaale [31] indicated that tomato growers in Uganda require slightly acidic soils with a pH level of 6.0 to 7.0 for high quality yields. Since the soil tests present a $\mathrm{pH}$ of $6.08-6.12$, it therefore means that the MUARIK soils could be suitable for tomato growing. Soil $\mathrm{pH}$ can be adjusted if necessary. If the $\mathrm{pH}$ is too low, lime is added to the soil. If it is too high, some sulphur is mixed to the soil [31]. However, these adjustments come at a cost to the farmer. In addition, pumpkins may be grown at MUARIK because they are tolerant of fairly acid conditions and liming should not be necessary unless the $\mathrm{pH}$ is less than 5.5.

Based on the $\mathrm{pH}$ results of $6.08-6.12$ (Table 3), passion fruits and cabbages can be grown at MUARIK after reducing the acidity by lime application for better yields. This is so because passion fruits have been associated with soils with a 
$\mathrm{pH}$ of 6.5 to 7.5 (22). Cabbage requires soils with $\mathrm{pH}$ in the range of $6.0-6.5$, making Kabanyolo a suitable site for production of cabbages [3]. In contrast, watermelons prefer a soil $\mathrm{pH}$ between 6.0 and 6.8 [23] making MUARIK is a suitable site. However, other parameters such as soil texture, soil organic matter at MAURIK fall below the required standards for watermelon propagation. Eggplants require a site with $\mathrm{pH} 5.5$ to 6.0 for its better growth and development [3]. Similarly, a soil pH in the range of 4.5 - 5.6 is optimal for pineapple production [33]. It therefore implies that lime must be applied to lower the $\mathrm{pH}$ of MUARIK soil from 6.12 to the required range of $4.5-5.6$ and $5.5-6.0$, respectively, before pineapples and eggplants are introduced.

Phosphorus was $12.42 \pm 3.65 \mathrm{ppm}$ in the top soil compared to $8.88 \pm 3.2 \mathrm{pmm}$ in the sub soil (Table 3). However, according to Obreza and Rhoads [33], the critical level of $\mathrm{P}$ is $10 \mathrm{mg} \cdot \mathrm{kg}^{-1}$. This threshold shows that phosphorus is a deficient nutrient in the MUARIK sub soils. The lower level of $\mathrm{P}$ could be due to the large quantities drawn by plants [8] from the sub-soil layer. Perhaps $P$ fixation is high as the soils in the area are highly weathered with potential of high content of aluminum oxides. The abrupt boundaries between horizons in the top and bottom pedons (Table 1) point to highly weathered soils. Phosphorus was also the most variable mineral in both the top and sub soil (Table 3). This could be attributed to the behavior of $\mathrm{P}$ in most soils. Fungo et al. [8] noted that $\mathrm{P}$ tends to move less than $\mathrm{Ca}$ and $\mathrm{K}$ because of various types of chemical reactions that may occur, rendering it insoluble. The quantity and availability of $\mathrm{P}$ ought to be improved prior to fruit and vegetable propagation at MUARIK.

Soil organic matter $(\mathrm{OM}), \mathrm{Ca}, \mathrm{K}$, and $\mathrm{Mg}$ were $4.81 \pm 0.35,7.92 \pm 0.76,0.47 \pm$ 0.13 and $1.70 \pm 0.17$, on average in the top soil, these parameters were $4.53 \pm$ $0.15,6.46 \pm 0.74,0.29 \pm 0.06$ and $1.37 \pm 0.16$ in the subsoil horizon respectively (Table 3). Similarly, Majaliwa [32] had earlier indicated MUARIK soils to have moderate to low fertility. According to Obreza and Rhoads [33], the critical levels of $\mathrm{Ca}, \mathrm{K}$, and $\mathrm{Mg}$ are 250, 45 and $33 \mathrm{mg} \cdot \mathrm{kg}^{-1}$, respectively. By these standards, potassium is the most deficient nutrient in MUARIK. For high fruit and vegetable yields, fertilizer application may be required. According to a guide by Adekunle et al. [23], the soil must be fertile with good organic matter content. Thus, for watermelon yields, the MUARIK soils ought to be amended with aged manure, seaweed, and/or compost before planting because watermelons are heavy feeders.

A correlation matrix (Table 4) shows sand and clay with the highest negative significant correlation $(\mathrm{r}=-0.94, p<0.01)$. The highest positive significant correlation was observed between $\mathrm{Ca}$ and $\mathrm{Mg}$ both in the topsoil $(\mathrm{r}=0.96, p<0.01)$ and subsoil $(\mathrm{r}=0.99, p<0.01)$. The observed high and negative correlation between sand and silt is not uncommon because these two soil properties are complementary to each other [8]. In contrast, the high positive correlation between $\mathrm{Ca}$ and $\mathrm{Mg}$ can be attributed to the possibility of the two minerals having similar parent material mineralogy. Chadwik and Graham [34] assert that mafic mantlederive rocks typically weather to a smectite and iron oxide-rich colloidal fraction 
with the simultaneous release of both $\mathrm{Ca}$ and $\mathrm{Mg}$.

\section{Conclusion}

This study reveals that the upper part of the studied pedons had dark yellowish brown to dark brown colour while lower soil layers were yellowish red. The texture of the studied soil profiles was generally clay (52\%). Furthermore, the soils were generally acidic with a pH of 6.08 to 6.12. The site was deficient in most of the minerals including $\mathrm{P}, \mathrm{Ca}, \mathrm{K}, \mathrm{Mg}, \mathrm{Na}, \mathrm{N}$, and soil organic matter (OM). Phosphorus was the most variable property in both the top and sub soil. Sand and clay had the highest negative significant correlation $(r=-0.94, p<0.01)$ in the top soil. Similarly, soil $\mathrm{pH}$ had the highest negative and significant relationship ( $\mathrm{r}=-0.88, \mathrm{p}<0.01$ ) with sand in the sub-soil layer. The highest positive significant correlation was observed between $\mathrm{Ca}$ and $\mathrm{Mg}$ both in the topsoil $(\mathrm{r}=$ 0.96, $\mathrm{p}<0.01)$ and subsoil $(\mathrm{r}=0.99, \mathrm{p}<0.01)$. Thus, MUARIK is suitable for cabbage and pumpkin because they grow on a wide range of soil types ranging from light sand to heavier soils. However, passion fruit and tomato should be grown at MUARIK after adjusting the soil pH with lime. Similarly, watermelon will require aged manure before planting because watermelons are heavy feeders and slight sulphur amendments are needed to accommodate eggplant and pineapple (Table 5).

\section{Acknowledgements}

Financial support was obtained from the German Federal Ministry of Education and Research under the Reduction of Post-Harvest Losses and Value Addition in East African Food Value Chains Project (RELOAD/A401UNCST2012). We are grateful for the support from the University of Kassel (Prof. Oliver Hensel and Michael Hesse) and management of the MUARIK especially Prof. Phinehas Tukamuhabwa, Prof. Jacob Godfrey Agea and Jimmy Wesiga. Mr. Edward Baka of the Makerere University Agriculture Soil Laboratory is appreciated for the assistance in the preparation and laboratory analysis of soil samples. Harryson Lyagoba, Esther Birungi Tendero and Phillip Kihumuro are commended for the support during soil sampling.

\section{References}

[1] Okalebo, J.R., Gathua, K.W. and Woomer, P.L. (2002) Laboratory Methods for Soil and Plant Analysis: A Working Manual. TSBF, Nairobi.

[2] Mahadevan, P. and Parsons, D.J. (1970) Livestock. In: Jameson, J. D., Ed., Agriculture in Uganda.

[3] Nono-Womdim, R., Ojiewo, C., Abang, M. and Oluoch, M.O., Eds. (2009) Good Agricultural Practices for African Indigenous Vegetables. Proceedings of a Technical Consultation Workshop in Arushia, Tanzania, 7-8 December 2009, International Society for Horticultural Science.

[4] Lal, R. (1994) Sustainable Land Use Systems and Soil Resilience. In: Greenland, D.J. and Szabolcs, I., Eds., Soil Resilience and Sustainable Land Use, CAB International Publishers, 41-67. 
[5] Pomeroy, D.E. (1977) Distribution and Abundance of Large Termite Mounds in Uganda. Journal of Applied Ecology, 14, 456-475. https://doi.org/10.2307/2402559

[6] Tenywa, M.M., Lal, R., Majaliwa, M.J.G. and Lufafa, A. (1999) Characterization of the Stages of Soil Resilience to Degradative Stresses: Erosion. In: Stott, D.E., Mohtar, R.H. and Steinhardt, G.C., Eds., Sustaining the Global Farm, The 10 th International Soil Conservation Organization Meeting, Purdue University and the USDA-ARS National Soil Erosion Research Laboratory, 24-29 May 1999, 606-610.

[7] Okwakol, M.J.N. and Sekamatte, M.B. (2007) Soil Macrofauna Research in Ecosystems in Uganda. African Journal of Ecology, 45, 2-8. https://doi.org/10.1111/j.0141-6707.2007.00800.x

[8] Fungo, B., Grunwald, S., Tenywa, M.M., Vanlauwe, B. and Nkedi-Kizza, P. (2011) Lunnyu Soils in the Lake Victoria Basin of Uganda: Link to Toposequence and Soil type. African Journal of Environmental Science and Technology, 5, 15-24.

[9] Mulumba, L.N. (2004) Land Us Effect on Soil Quality and Productivity in the Lake Victorial Basin of Uganda. Ph.D. Thesis, The Ohio State University, USA.

[10] Steenwerth, K.L., Jackson, L.E., Calderon, F.J., Stromberg, M.R. and Scow, K.M. (2002) Soil Community Composition and Land Use History in Cultivated and Grassland Ecosystems of Coastal California. Soil Biology and Biochemistry, 34, 1599-1611. https://doi.org/10.1016/S0038-0717(02)00144-X

[11] Yost, D. and Eswaran, H. (1990) Major Land Resource Areas of Uganda. World Soil Resources, Soil Conservation Service-USDA, Washington DC, 227 p.

[12] Komutunga, E.T. and Musiitwa, F. (2001) Climate. In: Mukiibi, J.K, Ed., Agriculture in Uganda, Volume 1: General Information, Fountain Publishers, Kampala, 21-32.

[13] Kisamba-Mugerwa, W. (2001) Social Background. In: Mukiibi, J.K, Ed., Agriculture in Uganda, Volume 1: General Information, Fountain Publishers, Kampala, 186199.

[14] Okia, C.A. (2010) Balanites aegyptiaca: A Resource for Improving Nutrition and Income of Dryland Communities in Uganda. PhD Thesis, University of Wales, Bangor, $310 \mathrm{p}$.

[15] Szymański, W., Skiba, M., Nikorych, V.A. and Kuligiewicz, A. (2014) Nature and Formation of Interlayer Fillings in Clay Minerals in Albeluvisols from the Carpathian Foothills, Poland. Geoderma, 235-236, 396-409. https://doi.org/10.1016/j.geoderma.2014.08.001

[16] MCC (1954) Munsel Colour Charts. Munsel Colour Company, Baltimore.

[17] Cleland, T.M. (1921) A Practical Description of the Munsell Color System with Suggestions for Its Use. Strathmore Paper Company, Russell.

[18] Bray, R.H. and Kurtz, L.T. (1945) Determination of Total, Organic, and Available Forms of Phosphorus in Soils. Soil Science, 59, 39-45. https://doi.org/10.1097/00010694-194501000-00006

[19] Rhoades, J.D. (1982) Soil Testing. In: Page, A, Miller, R.M. and Keeney, D.R., Eds., Methods of Soil Analysis, Part 2, 2nd Edition, Am. Soc. Agron, Madison, 16-21.

[20] Anderson, J.M. and Ingram, J.S.I. (1989) Tropical Soil Biology and Fertility. Handbook of Methods, CAB. International, Wallingford.

[21] United States Department of Agriculture (1987) Soil Mechanics Level 1 Module 3 USDA Soil Textural Classification Study Guide. USDA Soil Conservation Service, Washington DC.

[22] Morton, J. (1987) Passionfruit. In: Morton, J., Ed., Fruits of Warm Climates, Florida Flair Book, Miami, 320-328.

[23] Adekunle, A.A., Fatunbi, A.O., Adisa, S. and Adeyemi, O.A. (2007) Growing Wa- 
termelon Commercially in Nigeria: An Illustrated Guide. USAID ICSNIGERIA and IITA. http://www.fao.org/sd/erp/toolkit/BOOKS/watermelon_illust_guidebook.pdf

[24] Department of Agriculture and Fisheries (2013) Land Requirements for Growing Pineapples. Queensland Government.

https://www.daf.qld.gov.au/plants/fruit-and-vegetables/fruit-and-nuts/pineapples/la nd-requirements-pineapple

[25] Lindbo, D.L., Rhoton, F.E., Hudnall, W.H., Smeck, N.E., Bigham, J.M. and Tyler, D.D. (2000) Fragipan Degradation and Nodule Formation in Glossic Fragiudalfs of the Lower Mississippi River Valley. Soil Science Society of America Journal, 64, 1713-1722. https://doi.org/10.2136/sssaj2000.6451713x

[26] Szymański, W., Skiba, M. and Skiba, S. (2011) Fragipan Horizon Degradation and Bleached Tongues Formation in Albeluvisols of the Carpathian Foothills, Poland. Geoderma, 167-168, 340-350. https://doi.org/10.1016/j.geoderma.2011.07.007

[27] Mugagga, F., Kakembo, V. and Buyinza, M. (2011) A Characterisation of the Physical Properties of Soil and the Implications for Landslide Occurrence on the Slopes of Mount Elgon, Eastern Uganda. Natural Hazards, 52, 1113-1131.

[28] Baynes, F.J. (2008) Anticipating Problem Soils on Linear Projects. Conference Proceedings on Problem Soils in South Africa, Midrand, 3-4 November 2008, 9-21.

[29] Yang, H., Adler, R. and Huffman, G. (2007) Use of Satellite Remote Sensing in the Mapping of Global Landslide Susceptibility. Nat Hazards, 43, 245-256. https://doi.org/10.1007/s11069-006-9104-Z

[30] Wati, S.E., Hastuti, T., Wijojo, S. and Pinem, F. (2010) Landslide Susceptibility Mapping with Heuristic Approach in Mountainous Area. A Case Study in Tawangmangu Sub District, Central Java, Indonesia. International Archives of the Photogrammetry, Remote Sensing and Spatial Information Science, 38, 248-253.

[31] Muzaale, F. (2014) Growing Good Quality Tomatoes: Farming Magazines, Daily Monitor, Kampala, Uganda.

[32] Majaliwa, M.J.G. (1998) Effect Vegetation Cover and Biomass Development on Soil Loss from Maize Based Cropping Systems. MSc Dissertation, Makerere University, Kampala, 102 p.

[33] Obreza, T.A. and Rhoads, F.M. (1988) Irrigated Corn Response to Soil Test Indices and Fertilizer Nitrogen, Phosphorus, Potassium and Magnesium. Soil Science Society of America Journal, 52, 701-706. https://doi.org/10.2136/sssaj1988.03615995005200030020x

[34] Chadwik, O.A. and Graham, R.C. (2000) Pedogenic Processes. In: Sumner, M., Ed., CRC Handbook of Soil Science, CRC Press, New York, E41-E73. 
Submit or recommend next manuscript to SCIRP and we will provide best service for you:

Accepting pre-submission inquiries through Email, Facebook, LinkedIn, Twitter, etc. A wide selection of journals (inclusive of 9 subjects, more than 200 journals)

Providing 24-hour high-quality service

User-friendly online submission system

Fair and swift peer-review system

Efficient typesetting and proofreading procedure

Display of the result of downloads and visits, as well as the number of cited articles Maximum dissemination of your research work

Submit your manuscript at: http://papersubmission.scirp.org/

Or contact ojss@scirp.org 